Brown, Karl. "Gille, Zsuzsa. 2016. Paprika, Foie Gras, and Red Mud: The Politics of Materiality in the European Union. Bloomington: Indiana UP." Hungarian Cultural Studies. e-Journal of the American Hungarian Educators Association, Volume 11 (2018) DOI: 10.5195/ahea.2018.332

\title{
Gille, Zsuzsa. 2016. Paprika, Foie Gras, and Red Mud: The Politics of Materiality in the European Union. Bloomington: Indiana UP.
}

\section{Reviewed by Karl Brown*, University of Wisconsin, Whitewater}

In Paprika, Foie Gras, and Red Mud: The Politics of Materiality in the European Union, Zsuzsa Gille argues that the regulatory program of the European Union constitutes a new modality of power embedded in material culture to which Hungary (and other post-socialist countries) are uniquely subjected. While there is no dearth of scandals and controversies in Hungary's recent history, Gille suggests that three in particular - the 2004 paprika ban, the 2008 foie gras boycott, and the 2010 red mud spill—stand out as emblematic of the EU new politics of materiality at work. Each case occurred when the interests of Hungarian producers ran afoul of EU regulation, and the resolution of each case reveals how post-accession tensions between Western Europe and its East-Central European neighbors are mediated and resolved not via open political debate but rather by EU regulatory schema overriding its unruly new subjects.

After 1989, Hungary and the former countries of the Soviet Bloc began the laborious process of aligning their economies with the EU's policies as a precondition to joining the EU in 2004. This process entailed quotas on agricultural production (so that cheaper Eastern European foodstuffs would not compete with Western European producers) and following regulations covered everything from food safety and hygiene to animal rights and environmental safety, all in minute detail. This was a rigged game, but one in which Hungarian producers of those few commodities "that could be claimed to embody Hungarian national tradition and local or regional know-how" could still compete (21-24). Thus the 2004 paprika ban, which resulted from the discovery of aflatoxin in Hungarian-labeled paprika, acquired a political significance beyond its actual impact on food safety. Aflatoxin is a fungal contaminant, toxic in high doses; it is also native to warmer and moister climates than Hungary, such as Brazil and Spain. Its presence in Hungarian-labeled paprika revealed that Hungarian paprika processors were adulterating their product with imported peppers, damaging its perception as a Hungarikum, a quality (and uniquely Hungarian) product. Ironically enough, the prior relevant food safety standards in Hungary were more stringent than those imposed by the EU; Hungarian efforts to protect this key commodity by arguing for increased and more thorough testing were ignored by the other EU member states, in which pepper consumption and production are not as important. Thus, in this case, adopting EU regulations proved not only ineffective in controlling the spread of fungal contamination but also resulted in a severe decline for the Hungarian paprika industry (43).

*brownk@uww.edu

$($ (c) $)$ EY

ULIS D-Senle
New articles in this journal are licensed under a Creative Commons Attribution 4.0 International License.

This journal is published by the University Library System of the University of Pittsburgh as part of its D-Scribe Digital Publishing Program and is cosponsored by the University of Pittsburgh Press 
Brown, Karl. "Gille, Zsuzsa. 2016. Paprika, Foie Gras, and Red Mud: The Politics of Materiality in the European Union. Bloomington: Indiana UP." Hungarian Cultural Studies. e-Journal of the American Hungarian Educators Association, Volume 11 (2018) DOI: 10.5195/ahea.2018.332

Joining the European Union has subjected Hungary not only to supranational regulation but also animal-rights activism, as evinced by the 2008 campaign against Hungarian foie gras. The Austrian organization Vier Pfoten ['Four Paws'], or FP, launched a boycott against Hungarian foie gras primarily on the grounds that gavage, or the force-feeding of geese necessary for its production, is an inhumane process. Notably, Four Paws targeted Hungarian foie gras rather than the much larger French foie gras industry, which produces eight times as much but is well-protected. FP framed the debate as one of superior, "European" ethics squaring off against lesser, Hungarian values; its actions may also have been prompted by a shady connection to Weisenhof, a major German poultry supplier that would benefit from weakening its competitors (50). Attempts by the Hungarian Ministry of Agriculture to negotiate a compromise with FP proved unsuccessful, and Hungarian foie gras production suffered as a result. The parallel between paprika and foie gras is apparent: when subjected to EU-wide regimes (food safety in the former case, ethical in the latter), Hungarian producers lose out. Moreover, just as foreign and poorly-tested peppers have supplanted Hungarian paprika in the EU, the beneficiary in the foie gras contretemps will in all likelihood be China, where foie gras production is on the rise and no animal-protection laws stand in the way of the inhumane treatment of Chinese geese (54-55).

Gille then shifts from foodstuffs to industrial disaster, as she investigates the 2010 red mud spill in Ajka. Red mud, a highly-alkaline byproduct of aluminum production, had been stored in waste ponds since the communist period; its disposal had been monitored, however haphazardly, by a 1981 directive. The post-socialist transition had two significant effects: the state aluminum manufacturing concern was bought out by Magyar Alumínium Termelö és Kereskedelmi Zrt. ['Hungarian Aluminium Production and Commerce Ltd.'], or MAL, and the regulation of red-mud waste fell under the new EU schema. As with paprika, the new standards were actually more lenient than their state socialist precursors. Since most Western European countries had already transitioned to more effective means of processing aluminum, the EU did not label red mud a waste product; since it was cheaper and easier to deal with than were it treated as hazardous waste, MAL was quite willing to go along with this weakened regulatory scheme. Red mud can be treated to make it less toxic, but it did not make good financial sense: doing so was expensive, the red mud ponds provided added profit by (illegally) renting out waste-storage space to other companies, and new technologies that might make it possible to extract valuable heavy metals from aluminum production all militated against heeding environmental concerns. Red mud and other wastes piled up behind weakening walls until October 4, 2010, when a flood of toxic waste inundated three villages, killing ten people and destroying the Marcal river ecosystem; however, this waste had been oozing through the loophole created by the absence of effective regulation for over a decade previously.

Taken together, these three episodes in post-socialist Hungarian material-culture reveal the "politics of materiality" in the European Union today. Whereas previous regulatory schemes were created by legislators in concert with public deliberation, post-accession EU policies are imposed upon its newer, weaker members not following open debate but rather by imposition of these regulatory schema: "In sum, political goals have been achieved not with political tools but rather by material means. Politics has in effect been materialized" (131). This is not to say the European Union deliberately subordinates its post-socialist members to the interests of its Western members; rather, the regulatory (and with foie gras, the ethical) systems in place 
Brown, Karl. "Gille, Zsuzsa. 2016. Paprika, Foie Gras, and Red Mud: The Politics of Materiality in the European Union. Bloomington: Indiana UP." Hungarian Cultural Studies. e-Journal of the American Hungarian Educators Association, Volume 11 (2018) DOI: 10.5195/ahea.2018.332

inherently favor the latter, and they do so in a manner that makes it difficult if not impossible to resist. Gille argues that in the realm of politics as usual (if such a thing still exists in the world of Orbán, Brexit, and Trump), these politics of materiality have contributed to the rise of the New Right in Hungary, as its nationalistic appeals resonate with a population convinced it has been treated poorly by EU accession. The point, then, is not to deny the various ways in which Hungary has fared poorly after 2004, but rather explain them better: "instead of denying economic grievances and new inequalities within the EU, social scientists must provide alternative interpretations of their origins" in an effort to "diminish right wing voters' conviction that the EU is a rigged game and channel their justified grievances toward socially just, progressive, and more practical solutions" (135).

Overall, Paprika, Foie Gras, and Red Mud offers a novel analysis of these issues that have plagued post-accession East Central Europe, and the relationships that these countries have with their Western counterparts. Chapter 4, "Neoliberalism, Molecularization, and Governance," situates Gille's approach, which she labels global ethnography, in the broader field of social science theory. The latter is dense enough so one would hesitate to assign this book in an undergraduate course, yet Paprika, Foie Gras, and Red Mud remains well worth a read for scholars in our field. 